\title{
Immunobiological Properties of Lipopolysaccharides Isolated from Fusobacterium nucleatum and $F$. necrophorum
}

\author{
By NOBUO OKAHASHI, TOSHIHIKO KOGA,TATSUJI NISHIHARA, \\ TAKU FUJIWARA AND SHIGEYUKI HAMADA* $\dagger$ \\ Department of Dental Research, The National Institute of Health, Kamiosaki, Shinagawa-ku, \\ Tokyo 141, Japan
}

(Received 14 January 1988)

\begin{abstract}
Lipopolysaccharides (LPSs) were isolated from Fusobacterium nucleatum ATCC 10953 and $F$. necrophorum ATCC 25286 by the hot phenol/water procedure. $F$. nucleatum LPS was composed of $16 \%(\mathrm{w} / \mathrm{w})$ carbohydrate, $10 \%(\mathrm{w} / \mathrm{w})$ hexosamine and $40 \%(\mathrm{w} / \mathrm{w})$ fatty acid, while F. necrophorum LPS was composed of $26 \%(\mathrm{w} / \mathrm{w})$ carbohydrate, $12 \%(\mathrm{w} / \mathrm{w})$ hexosamine and $28 \%(\mathrm{w} / \mathrm{w})$ fatty acid. These LPS preparations induced mitogenic responses in spleen cells of $\mathrm{BALB} / \mathrm{c}, \mathrm{BALB} / \mathrm{c}(\mathrm{nu} / \mathrm{nu})$ and $\mathrm{C} 3 \mathrm{H} / \mathrm{HeN}$ mice, and these responses were suppressed by the addition of polymyxin $B$. The preparations also induced the polyclonal responses of $\mathrm{C} 3 \mathrm{H} / \mathrm{HeN}$ spleen cells. In addition, enhanced glucose utilization and interleukin-1 production by murine peritoneal macrophages were demonstrated. Neither spleen cells nor macrophages from the 'LPS-nonresponsive' $\mathrm{C} 3 \mathrm{H} / \mathrm{HeJ}$ mouse were activated by LPSs from the Fusobacterium species.
\end{abstract}

\section{INTRODUCTION}

Fusobacterium nucleatum and $F$. necrophorum are Gram-negative, obligatorily anaerobic filamentous bacteria. $F$. nucleatum is prominent in the bacterial flora of dental and subgingival plaques (Slots, 1979; Socransky et al., 1982), with higher numbers than normal commonly found in sites with gingivitis or periodontitis (Moore et al., 1982; Savitt \& Socransky, 1984). It has induced periodontitis in monoinfected gnotobiotic rats (Irving et al., 1978). F. necrophorum is rarely isolated from oral flora; however, it occasionally causes severe necrotic infections in man and animals (Duerden, 1983).

The pathogenicity of these Fusobacterium species may be related in part to their endotoxin (lipopolysaccharide; LPS) (Hofstad, 1982). It has been shown that the amount of endotoxin in gingival and periodontal tissues correlates with the severity of inflammation in these sites (Shapiro et al., 1972). Simon et al. (1972) also reported that the number of anaerobic Gramnegative rods in gingival exudates correlated with the amount of endotoxin in crevicular fluid as well as with the degree of tissue inflammation. Endotoxic biological properties of various LPS preparations isolated from Fusobacterium species have been studied by several workers. LPS from $F$. nucleatum produces local and generalized Shwartzman reactions, and it is lethal to mice and chick embryos, and pyrogenic in rabbits (Mashimo et al., 1985; Sveen, 1977; Sveen et al., 1977). It can also activate human and guinea-pig complements (Hawley \& Falkler, 1978; Nygren et al., 1979), and stimulate bone resorption (Sveen \& Skaug, 1980). LPS from $F$. necrophorum also possesses various endotoxic activities (Garcia et al., 1975; Warner et al., 1975). However, little is known about the immunobiological potencies of Fusobacterium LPS with

$\dagger$ Present address: Department of Oral Microbiology, Osaka University Faculty of Dentistry, 1-8 Yamadaoka, Suita, Osaka, 565 Japan.

Abbreviations: Con A, concanavalin A; FCS, foetal calf serum; IL-1, interleukin-1; KDO, 2-keto-3deoxyoctonate (3-deoxy-D-manno-2-octulosonic acid); PFC, plaque-forming cell(s); SRBC, sheep red blood cell(s). 
respect to lymphoid cells and macrophages. In this study, we isolated and characterized LPSs from $F$. nucleatum and $F$. necrophorum by the hot phenol/water procedure, and investigated their immunobiological properties.

\section{METHODS}

Bacterial strains and growth conditions. F. nucleatum ATCC 10953 was kindly supplied by Dr T. Umemoto, Department of Oral Bacteriology, Kanagawa Dental College, Yokosuka, Japan. F. necrophorum ATCC 25286 was obtained from the American Type Culture Collection, Rockville, Md, USA. The bacteria were grown in Brain Heart Infusion broth (Difco) supplemented with $0.5 \%(\mathrm{w} / \mathrm{v})$ yeast extract (Difco) and cysteine. $\mathrm{HCl}\left(0 \cdot 3 \mathrm{mg} \mathrm{ml}^{-1}\right.$ ) at $37^{\circ} \mathrm{C}$ for $3 \mathrm{~d}$ in air $/ \mathrm{CO}_{2}(95: 5, \mathrm{v} / \mathrm{v})$. Organisms were harvested by centrifugation at $6000 \mathrm{~g}$ for $30 \mathrm{~min}$, washed three times with pyrogen-free water, and lyophilized.

Extraction and purification of LPS. LPS was isolated from lyophilized cells by the hot phenol/water extraction procedure of Westphal \& Jann (1965). The crude extract was treated with nuclease, washed extensively with pyrogen-free water by ultracentrifugation, and lyophilized (Koga et al., 1985). This preparation was referred to as 'partially purified' LPS. The partially purified preparation was dissolved in pyrogen-free water at a concentration of $2 \mathrm{mg} \mathrm{ml}^{-1}$, and an equal volume of $90 \%(\mathrm{v} / \mathrm{v})$ phenol was added. The mixture was stirred vigorously at $65^{\circ} \mathrm{C}$ for $30 \mathrm{~min}$, and the aqueous phase was then collected. This extraction procedure was repeated once more. The combined aqueous phases were dialysed extensively against distilled water, lyophilized, and the product termed 'purified' LPS. LPS from Escherichia coli K235 was isolated and purified as described previously (Koga $e t$ al., 1985).

Chemical analyses. Hexose, hexosamine, heptose, 2-keto-3-deoxyoctonate (KDO), protein, fatty acid esters, and phosphorus were assayed by the colorimetric methods previously described (Koga et al., 1985). For sugar and fatty acid analyses, LPS was hydrolysed for $6 \mathrm{~h}$ at $100^{\circ} \mathrm{C}$ in $2 \mathrm{M}-\mathrm{HCl}$. The hydrolysate was suspended in chloroform/methanol/water (4:10:5, by vol.) and mixed vigorously. The aqueous and chloroform phases were separated by centrifugation, and were processed for the sugar and fatty acid analyses, respectively. Neutral and amino sugars in the aqueous phase were identified as trimethylsilyl or alditol acetate derivatives by gas-liquid chromatography (GLC), and fatty acids in the chloroform phase were quantified as their methyl esters by GLC (Koga et al., 1985).

Mitogenic and polyclonal $B$ cell activation activities. Mitogenic activity of LPS for spleen cells from BALB/c, $\mathrm{BALB} / \mathrm{c}(\mathrm{nu} / \mathrm{nu}), \mathrm{C} 3 \mathrm{H} / \mathrm{HeN}$ and $\mathrm{C} 3 \mathrm{H} / \mathrm{HeJ}$ mice, and for thymocytes from BALB/c mice, was determined as previously described (Koga et al., 1985). Spleen cells $\left(5 \times 10^{5}\right)$ were suspended in $0.2 \mathrm{ml}$ RPMI 1640 medium supplemented with penicillin $\left(100 \mathrm{U} \mathrm{ml}^{-1}\right)$, streptomycin $\left(100 \mu \mathrm{g} \mathrm{ml}^{-1}\right)$ and HEPES buffer $(15 \mathrm{mM}, \mathrm{pH} \mathrm{7.2)}$ (hereafter, this medium is referred to simply as RPMI 1640 medium), and were cultured with various stimulants at $37^{\circ} \mathrm{C}$ in a humidified atmosphere of air $/ \mathrm{CO}_{2}(95: 5, \mathrm{v} / \mathrm{v})$. Cultures were pulsed for the final $6 \mathrm{~h}$ of incubation with $\left[{ }^{3} \mathrm{H}\right]$ thymidine $\left(0.25 \mu \mathrm{Ci}, 9.25 \mathrm{kBq}\right.$; Amersham), and then the amount of $\left[{ }^{3} \mathrm{H}\right]$ thymidine uptake was determined. Concanavalin A (Con A; Sigma) was used as a T-cell mitogen. The effect of polymyxin B (Sigma) on mitogenic responses of BALB/c spleen cells to LPS was examined as follows. Spleen cells $\left(5 \times 10^{5}\right)$ were cultured in $0.2 \mathrm{ml}$ RPMI 1640 medium containing various amounts of polymyxin B $(0-5 \mu \mathrm{g})$ and $5 \mu \mathrm{g}$ of stimulant. The mitogenic responses were determined as described above.

In vitro polyclonal B cell activation activity of $\mathrm{LPS}$ for $\mathrm{C} 3 \mathrm{H} / \mathrm{HeN}$ and $\mathrm{C} 3 \mathrm{H} / \mathrm{HeJ}$ spleen cells was determined as previously described (Koga et al., 1985). After incubation for $4 \mathrm{~d}$ at $37^{\circ} \mathrm{C}$ in air $/ \mathrm{CO}_{2}(95: 5, \mathrm{v} / \mathrm{v})$, cells were removed from each culture well, washed, and assayed for direct anti-sheep erythrocyte plaque-forming cell (antiSRBC PFC) responses by the haemolytic plaque technique of Cunningham \& Szenberg (1968).

Glucose consumption by peritoneal macrophages. Macrophage activation was evaluated by the glucose consumption assay described by Ryan et al. (1979). Murine peritoneal macrophages were induced by intraperitoneal injection of $2 \mathrm{ml} \mathrm{10 \% (w/v)} \mathrm{Trypticase} \mathrm{peptone} \mathrm{(BBL).} \mathrm{Four} \mathrm{days} \mathrm{later,} \mathrm{peritoneal} \mathrm{exudate} \mathrm{cells}$ were collected by peritoneal lavage with $5 \mathrm{ml}$ Hanks' balanced salt solution (GIBCO) containing $1 \%$ (v/v) foetal calf serum (FCS; Armour Pharmaceutical Co.), washed, and resuspended in RPMI 1640 medium containing 5\% (v/v) FCS. Peritoneal macrophages $\left(6 \times 10^{5}\right)$ were placed in 96-well microtitre plates and incubated for $3 \mathrm{~h}$ at $37^{\circ} \mathrm{C}$ in air $/ \mathrm{CO}_{2}(95: 5, \mathrm{v} / \mathrm{v})$, then nonadherent cells were removed by washing with RPMI 1640 medium. The adherent cells were cultured in $0.2 \mathrm{ml}$ RPMI 1640 medium with or without stimulant at $37^{\circ} \mathrm{C}$ in air $/ \mathrm{CO}_{2}(95: 5$, $v / v)$, and samples $(5 \mu \mathrm{l})$ of the culture supernatant were assayed for glucose using a blood sugar GOD-Perid test kit (Boehringer Mannheim). The results were expressed as percentages of the initial glucose concentration in the culture supernatants. Each assay was done on triplicate cultures.

Induction of interleukin-1 (IL-1) production by peritoneal macrophages. Peritoneal macrophages $\left(3 \times 10^{6}\right)$ prepared as described above were cultured in $1 \mathrm{ml} \mathrm{RPMI} 1640$ with or without stimulant at $37^{\circ} \mathrm{C}$ in air/ $/ \mathrm{CO}_{2}(95: 5$, v/v) for $24 \mathrm{~h}$. The culture supernatant was harvested by centrifugation, and passed through a filter membrane $(0 \cdot 45 \mu \mathrm{m}$ pore size, Millipore). IL-1 activity in the culture supernatant was quantified by measuring the incorporation of $\left[{ }^{3} \mathrm{H}\right]$ thymidine into $\mathrm{C} 3 \mathrm{H} / \mathrm{HeJ}$ mouse thymocytes (Vacheron et al., 1983). The cells $\left(1.5 \times 10^{6}\right)$ were cultured for 
$72 \mathrm{~h}$ at $37^{\circ} \mathrm{C}$ in RPMI 1640 containing $10 \%(v / v)$ FCS, Con A $\left(1 \mu \mathrm{g} \mathrm{ml}^{-1}\right)$ and test sample. They were pulsed for the final $24 \mathrm{~h}$ with $0.5 \mu \mathrm{Ci}(18.5 \mathrm{kBq})\left[{ }^{3} \mathrm{H}\right]$ thymidine.

\section{RESULTS}

Chemical composition of LPSs from Fusobacterium spp.

Purified LPS from $F$. nucleatum ATCC 10953 ( $F$. nucleatum LPS) contained (w/w) $15.9 \%$ carbohydrate, $10.4 \%$ amino sugar, $40.0 \%$ fatty acid and $4.9 \%$ phosphorus. Purified LPS from $F$. necrophorum ATCC 25286 ( $F$. necrophorum LPS) contained $26.1 \%$ carbohydrate, $11.5 \%$ amino sugar, $27.9 \%$ fatty acid and $3.1 \%$ phosphorus. These LPS preparations contained less than $2 \%$ protein as determined by the Lowry procedure. The major sugars in $F$. nucleatum LPS were galactose and heptose, whereas those in $F$. necrophorum LPS were glucose and heptose. The major fatty acids in $F$. nucleatum LPS were myristic (C14:0), $\beta$-hydroxymyristic (3-OH C14:0) and $\beta$-hydroxypalmitic (3-OH $\mathrm{C16}: 0$ ) acids. $F$. necrophorum LPS did not contain $\beta$ hydroxypalmitic acid (data not shown).

\section{Mitogenic and polyclonal B-cell activation activities of LPS}

Purified LPSs from $F$. nucleatum and $F$. necrophorum were mitogenic for spleen cells of BALB/c and BALB/c (nu/nu) mice, but not for BALB/c thymocytes (Table 1). Similar activities were also found with the reference $E$. coli LPS. These results indicate that LPSs from $F$ usobacterium species, like $E$. coli LPS, are B-cell mitogens. Purified LPS preparations from $F$. nucleatum and $F$. necrophorum were clearly mitogenic for spleen cells of $\mathrm{C} 3 \mathrm{H} / \mathrm{HeN}$ mice but not for those of $\mathrm{C} 3 \mathrm{H} / \mathrm{HeJ}$ mice (Fig. $1 a, b$ ). However, 'partially purified' LPSs from both species were significantly mitogenic for $\mathrm{C} 3 \mathrm{H} / \mathrm{HeJ}$ spleen cells (Fig. $1 c, d$ ). This may have been due to contaminating endotoxic proteins, since these 'partially purified' LPS preparations contained significant amounts of protein $(5.9 \%$ and $4.3 \%$ for $F$. nucleatum and $F$. necrophorum, respectively).

We examined the effect of polymyxin B, which inhibits mitogenic activity of Enterobacteriaceae LPS, on the mitogenicity of LPSs from the Fusobacterium species (Fig. 2). Polymyxin B markedly suppressed the mitogenic activity of purified LPSs from Fusobacterium species as well as that of LPS from $E$. coli, but it only weakly inhibited the mitogenicity of Con A, used as a reference T-cell mitogen.

Purified LPSs from both $F$. nucleatum and $F$. necrophorum enhanced in vitro direct PFC responses of $\mathrm{C} 3 \mathrm{H} / \mathrm{HeN}$ spleen cells to $\mathrm{SRBC}$, but not those of $\mathrm{C} 3 \mathrm{H} / \mathrm{HeJ}$ spleen cells (Table 2). These results suggest that the LPS preparations induced polyclonal IgM synthesis in $\mathrm{C} 3 \mathrm{H} / \mathrm{HeN}$ but not in $\mathrm{C} 3 \mathrm{H} / \mathrm{HeJ}$ mice. Both LPS preparations showed in vitro adjuvant activity for $\mathrm{C} 3 \mathrm{H} / \mathrm{HeN}$ spleen cells, but not for $\mathrm{C} 3 \mathrm{H} / \mathrm{HeJ}$ spleen cells (data not shown).

\section{Activation of macrophages by LPS}

The ability of the purified LPSs to enhance the metabolic rate of macrophages was evaluated by measuring glucose consumption. Both $F$. nucleatum and $F$. necrophorum LPSs enhanced glucose utilization by BALB/c peritoneal macrophages, to the same extent as $E$. coli LPS (Fig. 3). $\mathrm{C} 3 \mathrm{H} / \mathrm{HeJ}$ macrophages were not stimulated by these LPS preparations (Fig. 4).

IL-1 activity in the culture supernatant of peritoneal macrophages was assessed by measuring the incorporation of $\left[{ }^{3} \mathrm{H}\right]$ thymidine by $\mathrm{C} 3 \mathrm{H} / \mathrm{HeJ}$ thymocytes. Both $F$. nucleatum and $F$. necrophorum LPSs stimulated $\mathrm{C} 3 \mathrm{H} / \mathrm{HeN}$ macrophages but not $\mathrm{C} 3 \mathrm{H} / \mathrm{HeJ}$ macrophages, to produce IL-1 activity (Table 3 ).

\section{DISCUSSION}

Chemical analyses revealed that $F$. nucleatum and $F$. necrophorum possess a 'classical' LPS which contains KDO, heptose and $\beta$-hydroxymyristic acid. The sugar and fatty acid compositions that we found for $F$. nucleatum LPS are essentially similar to those reported previously (Hase et al., 1977; Hofstad, 1982; Hofstad \& Skaug, 1980; Kristoffersen \& Hofstad, 


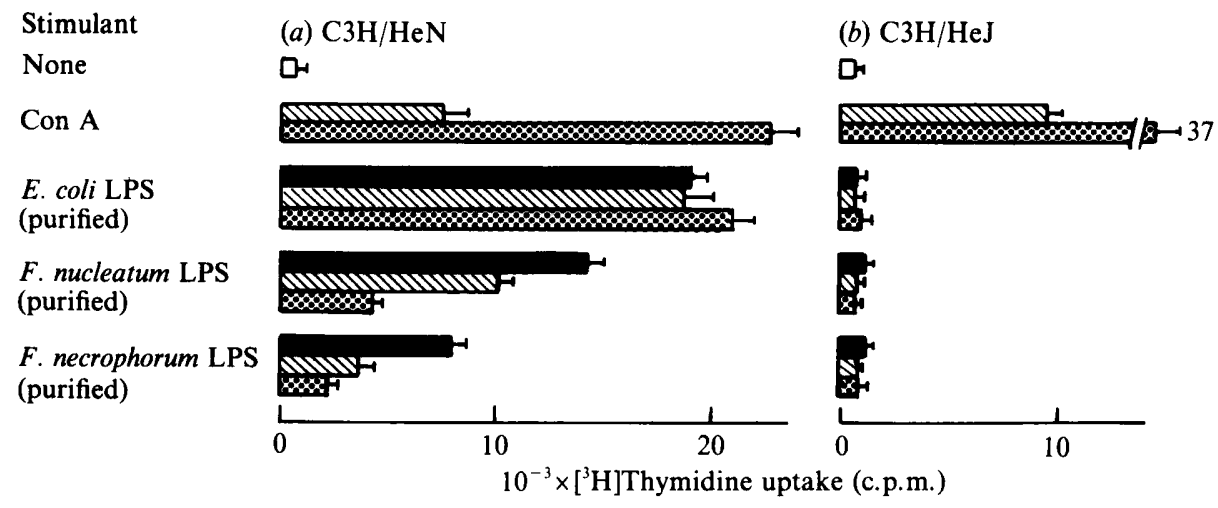

\begin{tabular}{|c|}
\hline None \\
\hline Con A \\
\hline $\begin{array}{l}\text { E. coli LPS } \\
\text { (purified) }\end{array}$ \\
\hline $\begin{array}{l}F . \text { nucleatum LPS } \\
\text { ('partially purified') }\end{array}$ \\
\hline $\begin{array}{l}\text { F. necrophorum LPS } \\
\text { ('partially purified') }\end{array}$ \\
\hline
\end{tabular}

(c) $\mathrm{C} 3 \mathrm{H} / \mathrm{HeN}$

or

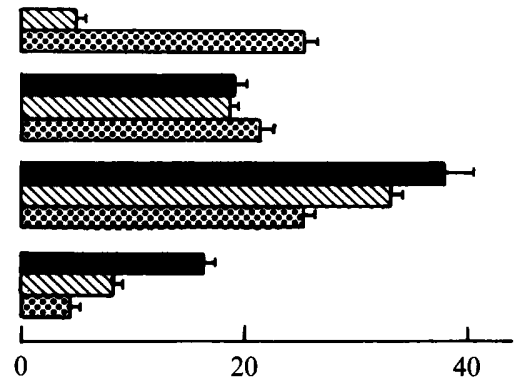

(d) $\mathrm{C} 3 \mathrm{H} / \mathrm{HeJ}$

[o

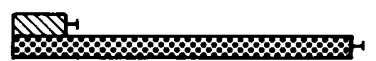

A

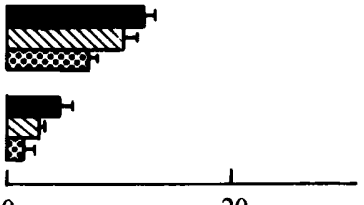

$10^{-3} \times\left[{ }^{3} \mathrm{H}\right]$ Thymidine uptake (c.p.m.)

Fig. 1. Mitogenic responses of $\mathrm{C} 3 \mathrm{H} / \mathrm{HeN}(a, c)$ and $\mathrm{C} 3 \mathrm{H} / \mathrm{HeJ}(b, d)$ mouse spleen cells to purified LPSs $(a, b)$ and 'partially purified' LPSs $(c, d)$. Spleen cells $\left(5 \times 10^{5}\right)$ were cultured for $48 \mathrm{~h}$ with $1 \mu \mathrm{g}(\infty)$, $5 \mu \mathrm{g}(\square)$ or $10 \mu \mathrm{g}(\square)$ stimulant per well, or without stimulant $(\square)$, in $0.2 \mathrm{ml}$ RPMI 1640 medium. Data are expressed as the mean \pm SD of triplicate cultures.

Table 1. Mitogenic responses of BALB/c spleen cells, thymus cells and BALB/c (nu/nu) spleen cells to purified LPSs from Fusobacterium spp.

Spleen cells or thymocytes $\left(5 \times 10^{5}\right.$ per well in $0.2 \mathrm{ml}$ RPMI 1640 medium) were cultured for $48 \mathrm{~h}$ with or without stimulant. Values are expressed as the mean \pm SD of triplicate cultures.

$\left[{ }^{3} \mathrm{H}\right]$ Thymidine uptake (c.p.m.)

Stimulant

None

Con A

E. coli $\mathrm{K} 235$

LPS

F. nucleatum

ATCC 10953 LPS

F. necrophorum

ATCC 25286 LPS

\section{Dose ( $\mu \mathrm{g}$ per well)}

10

5

1

10

5

1

10

5

$\begin{array}{ccc}\begin{array}{c}\text { BALB/c } \\ \text { spleen cells }\end{array} & \begin{array}{c}\text { BALB/c } \\ \text { thymus cells }\end{array} & \begin{array}{c}\text { BALB/c (nu/nu) } \\ \text { spleen cells }\end{array} \\ 937 \pm 229 & 495 \pm 91 & 971 \pm 195 \\ 3945 \pm 1574 & 26539 \pm 3751 & 643 \pm 111 \\ 30560 \pm 6509 & 16651 \pm 2560 & 594 \pm 36 \\ 19377 \pm 2894 & 1040 \pm 598 & 996 \pm 77 \\ 9595 \pm 2414 & 777 \pm 425 & 10501 \pm 1416 \\ 19561 \pm 3463 & 570 \pm 274 & 9840 \pm 721 \\ 15561 \pm 2146 & 369 \pm 54 & 7678 \pm 672 \\ 10393 \pm 1159 & 640 \pm 447 & 11739 \pm 2278 \\ 11843 \pm 1353 & 612 \pm 360 & 7016 \pm 689 \\ 3357 \pm 131 & 660 \pm 220 & 2994 \pm 496 \\ .5782 \pm 855 & 396 \pm 56 & 6923 \pm 850 \\ 3742 \pm 395 & 430 \pm 35 & 4779 \pm 209 \\ 1859 \pm 225 & 289 \pm 47 & 2219 \pm 189\end{array}$




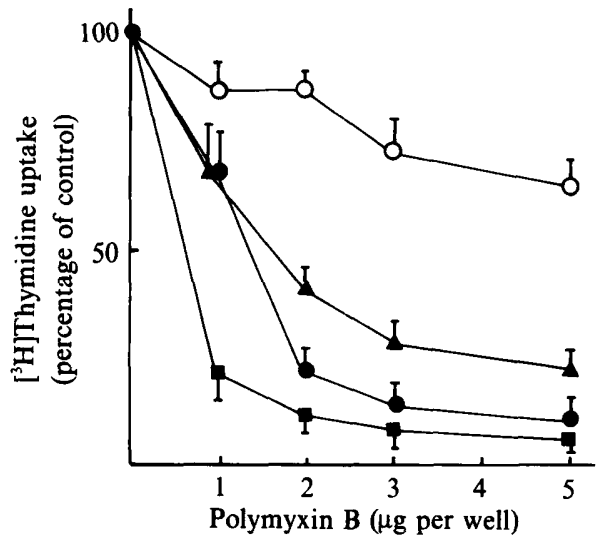

Fig. 2

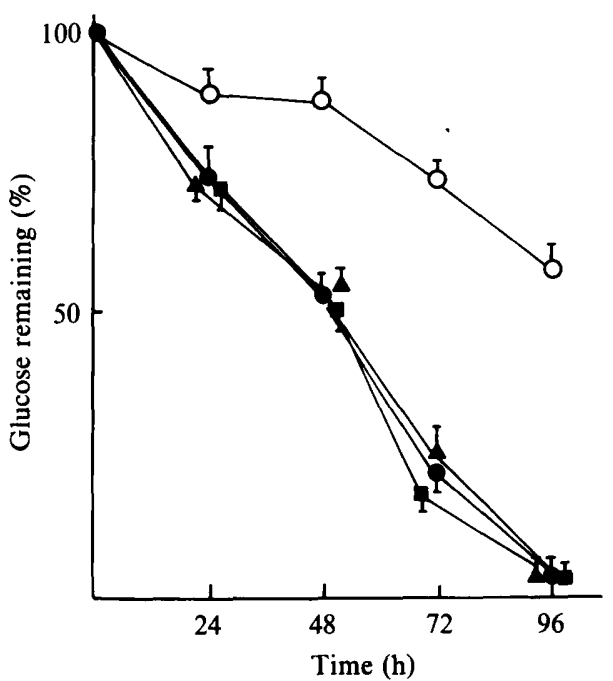

Fig. 3

Fig. 2. Effects of polymyxin B on mitogenic responses of BALB/c mouse spleen cells. Cells $\left(5 \times 10^{5}\right)$ were cultured for $48 \mathrm{~h}$ with $5 \mu \mathrm{g}$ of Con A $(O), E$. coli LPS $(O), F$. nucleatum LPS $(A)$ or $F$. necrophorum LPS $(\square)$ in $0.2 \mathrm{ml}$ RPMI 1640 medium containing various amounts of polymyxin $B$. Control spleen cell cultures to which no polymyxin B had been added responded as follows: Con A, 17361 c.p.m.; E. coli LPS, 12352 c.p.m.; F. nucleatum LPS, 11486 c.p.m.; F. necrophorum LPS, 7466 c.p.m.

Fig. 3. Ability of purified LPSs from $F$. nucleatum and $F$. necrophorum to increase glucose utilization by BALB/c peritoneal macrophages. Macrophages (obtained from $6 \times 10^{5}$ peritoneal exudate cells) were cultured with $10 \mu \mathrm{g}$ of $\boldsymbol{E}$. coli LPS (O),F. nucleatum LPS $(\boldsymbol{A})$ or $\boldsymbol{F}$. necrophorum LPS ( $\square$ ) per well, or without stimulant $(O)$, in $0.2 \mathrm{ml}$ RPMI 1640 medium. Glucose consumption was assayed as described in Methods.

Table 2. Polyclonal B cell activation by purified LPSs from Fusobacterium spp.

Spleen cells $\left(1 \times 10^{6}\right)$ from $\mathrm{C} 3 \mathrm{H} / \mathrm{HeN}$ and $\mathrm{C} 3 \mathrm{H} / \mathrm{HeJ}$ mice were incubated with stimulant in $0.2 \mathrm{ml}$ RPMI 1640 medium supplemented with $10 \%$ (v/v) FCS. After $4 \mathrm{~d}$ incubation, PFC responses were determined. Values are expressed as the mean $\pm \mathrm{SD}$ of four different cultures.

\begin{tabular}{|c|c|c|c|}
\hline \multirow[b]{3}{*}{ Source of stimulant LPS } & \multirow{3}{*}{$\begin{array}{c}\text { Dose } \\
(\mu \mathrm{g} \text { per well) }\end{array}$} & \multicolumn{2}{|c|}{ No. of PFC per well } \\
\hline & & Sple & ells: \\
\hline & & $\mathrm{C} 3 \mathrm{H} / \mathrm{HeN}$ & $\mathrm{C} 3 \mathrm{H} / \mathrm{HeJ}$ \\
\hline None & - & $9 \pm 3$ & $6 \pm 3$ \\
\hline E. coli $\mathrm{K} 235$ & $\begin{array}{l}10 \\
2 \\
0 \cdot 2\end{array}$ & $\begin{array}{l}46 \pm 5 \\
69 \pm 6 \\
53 \pm 13\end{array}$ & $\begin{array}{l}6 \pm 4 \\
4 \pm 2 \\
5 \pm 2\end{array}$ \\
\hline F. nucleatum ATCC 10953 & $\begin{array}{c}10 \\
2 \\
0 \cdot 2\end{array}$ & $\begin{array}{l}61 \pm 7 \\
51 \pm 5 \\
38 \pm 5\end{array}$ & $\begin{array}{l}6 \pm 2 \\
4 \pm 2 \\
5 \pm 2\end{array}$ \\
\hline F. necrophorum AТCC 25286 & $\begin{array}{c}10 \\
2 \\
0 \cdot 2\end{array}$ & $\begin{array}{l}53 \pm 4 \\
46 \pm 8 \\
24 \pm 6\end{array}$ & $\begin{array}{l}8 \pm 3 \\
4 \pm 3 \\
4 \pm 1\end{array}$ \\
\hline
\end{tabular}

1970; Mashimo et al., 1985; Wollenweber et al., 1984). LPS from $F$. necrophorum ATCC 25286 did not contain $\beta$-hydroxypalmitic acid, in agreement with the findings of Hofstad \& Skaug (1980) for LPSs from other $F$. necrophorum strains.

LPSs from Fusobacterium species have been reported to possess various endotoxic activities (Garcia et al., 1975; Hawley \& Falkler, 1978; Mashimo et al., 1985; Nygren et al., 1979; Sveen, 


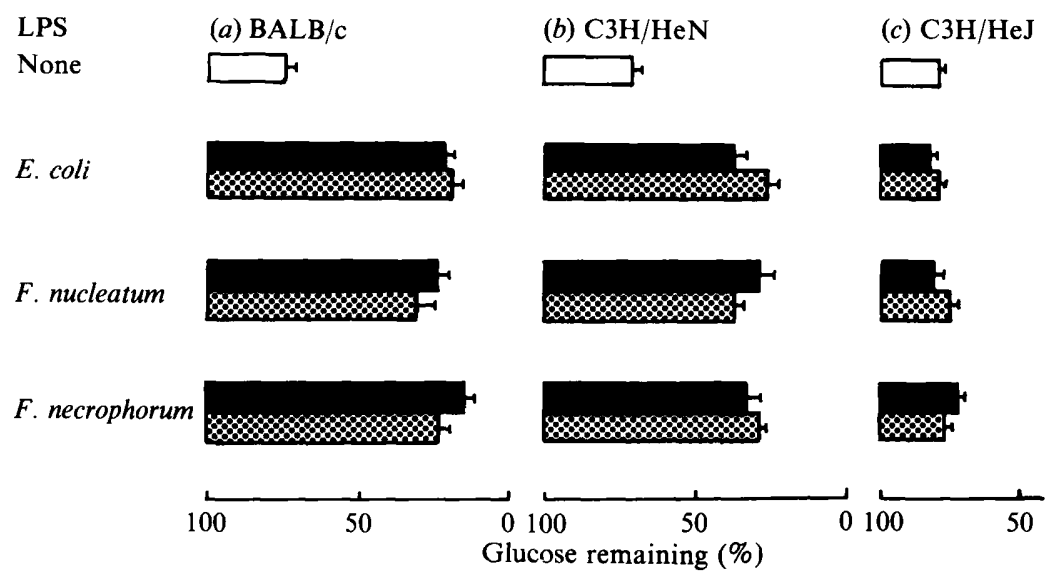

Fig. 4. Glucose consumption of $\mathrm{BALB} / \mathrm{c}(a), \mathrm{C} 3 \mathrm{H} / \mathrm{HeN}(b)$ and $\mathrm{C} 3 \mathrm{H} / \mathrm{HeJ}(c)$ peritoneal macrophages treated with purified LPSs from $F$. nucleatum, $F$. necrophorum and $E$. coli. Macrophages (obtained from $6 \times 10^{5}$ peritoneal exudate cells) were cultured for $72 \mathrm{~h}$ in the presence of $10 \mu \mathrm{g}(\boldsymbol{\omega})$ or $2 \mu \mathrm{g}(\boldsymbol{\omega})$ of stimulant per well in $0.2 \mathrm{ml}$ RPMI 1640 medium. Glucose consumption was assayed as described in Methods.

Table 3. Induction by LPSs from Fusobacterium spp. of IL-1 secretion by macrophages from $\mathrm{C} 3 \mathrm{H} / \mathrm{HeN}$ and $\mathrm{C} 3 \mathrm{H} / \mathrm{HeJ}$ mice

\begin{abstract}
Macrophages $\left(3 \times 10^{6}\right)$ were cultured for $24 \mathrm{~h}$ in the presence of stimulant in $1 \mathrm{ml}$ RPMI 1640 medium. The culture supernatant $(1: 2$ dilution; $0 \cdot 1 \mathrm{ml})$ and an equal volume of $\mathrm{C} 3 \mathrm{H} / \mathrm{HeJ}$ thymocytes suspension $\left(1.5 \times 10^{7} \mathrm{ml}^{-1}\right)$ were seeded into a 96-well microculture plate. Cultivation was carried out in the presence of Con $\mathrm{A}\left(0 \cdot 2 \mu \mathrm{g}\right.$ per well). The basal values of $\left[{ }^{3} \mathrm{H}\right]$ thymidine incorporation were $409 \pm 163$ c.p.m. for $\mathrm{C} 3 \mathrm{H} / \mathrm{HeN}$ macrophage supernatants and $538 \pm 66$ c.p.m. for $\mathrm{C} 3 \mathrm{H} / \mathrm{HeJ}$ macrophage supernatants.
\end{abstract}

\begin{tabular}{|c|c|c|c|}
\hline \multirow{3}{*}{$\begin{array}{l}\text { Stimulant added to } \\
\text { macrophage culture }\end{array}$} & \multirow{3}{*}{$\begin{array}{c}\text { Concn } \\
\left(\mu \mathrm{g} \mathrm{ml} \mathrm{m}^{-1}\right)\end{array}$} & \multicolumn{2}{|c|}{ Relative $\left[{ }^{3} \mathrm{H}\right]$ thymidine uptake } \\
\hline & & \multirow{2}{*}{\multicolumn{2}{|c|}{$\begin{array}{l}\text { Macrophage supernatant: } \\
\mathrm{C} 3 \mathrm{H} / \mathrm{HeN}\end{array}$}} \\
\hline & & & \\
\hline None & - & $1 \cdot 0$ & 1.0 \\
\hline Silica & 100 & $10 \cdot 6$ & $3 \cdot 2$ \\
\hline E. coli K235 LPS & $\begin{array}{l}50 \\
25 \\
10\end{array}$ & $\begin{array}{l}16.9 \\
19 \cdot 3 \\
13.7\end{array}$ & $\begin{array}{l}1 \cdot 1 \\
1 \cdot 2 \\
0.9\end{array}$ \\
\hline $\begin{array}{l}\text { F. nucleatum } \\
\text { ATCC } 10953 \text { LPS }\end{array}$ & $\begin{array}{l}50 \\
25 \\
10\end{array}$ & $\begin{array}{l}6.0 \\
8.7 \\
5.7\end{array}$ & $\begin{array}{l}1.3 \\
1 \cdot 1 \\
0.9\end{array}$ \\
\hline $\begin{array}{l}F . \text { necrophorum } \\
\text { ATCC } 25286 \text { LPS }\end{array}$ & $\begin{array}{l}50 \\
25 \\
10\end{array}$ & $\begin{array}{l}7 \cdot 1 \\
7 \cdot 3 \\
4 \cdot 0\end{array}$ & $\begin{array}{l}1.0 \\
0.9 \\
1.0\end{array}$ \\
\hline
\end{tabular}

1977; Sveen et al., 1977). In addition to these findings, the present study shows that the purified LPS preparations from $F$. nucleatum and $F$. necrophorum are B-cell mitogens, because they stimulated spleen cells of $B A L B / c$ and BALB/c $(\mathrm{nu} / \mathrm{nu})$ mice, but not BALB/c mouse thymocytes (Table 1). Moreover, the purified LPS preparations induced in vitro direct PFC responses to SRBC (Table 2). These LPS preparations stimulated spleen cells of the $\mathrm{C} 3 \mathrm{H} / \mathrm{HeN}$ mouse, but not those of the $\mathrm{C} 3 \mathrm{H} / \mathrm{HeJ}$ mouse, an LPS-nonresponder (Fig. $1 a, b$ ). In addition, polymyxin B, which inhibits the mitogenic activity of Enterobacteriaceae LPS (Jacobs \& Morrison, 1977), inhibited the mitogenic activity of Fusobacterium LPS (Fig. 2). These results indicate that LPS from $F$. nucleatum and $F$. necrophorum possesses biological activities similar to those of LPS from Enterobacteriaceae. 
The genus Fusobacterium is a member of the family Bacteroidaceae (Holdeman et al., 1984). However, LPS from Bacteroides species has been reported to be quite different from that of Enterobacteriaceae, in not containing KDO, heptose or $\beta$-hydroxymyristic acid (Hofstad, 1982; Joiner et al., 1982; Koga et al., 1985; Nair et al., 1983; Wollenweber et al., 1980, 1984). Moreover, the biological activities of Bacteroides LPSs are atypical; they give weak responses in most tests of endotoxic activity (Sveen, 1977; Sveen et al., 1977), and can act as potent mitogens for spleen cells from endotoxin-nonresponder C3H/HeJ mice (Joiner et al., 1982; Koga et al., 1985; Williamson et al., 1984). Williamson et al. (1984) showed that the polysaccharide moiety of LPS from Bacteroides is biologically active and mediates the stimulation of B-cells from $\mathrm{C} 3 \mathrm{H} / \mathrm{HeJ}$ mice via macrophages. Thus, the present study reveals that Fusobacterium LPS differs from Bacteroides LPS in biological activities as well as chemical properties, although Fusobacterium species belong to the family Bacteroidaceae.

The 'partially purified' LPS preparations from both Fusobacterium strains were mitogenic for $\mathrm{C} 3 \mathrm{H} / \mathrm{HeJ}$ spleen cells (Fig. $1 c, d$ ). The LPS-protein complex is known to be strongly mitogenic for $\mathrm{B}$ cells of the $\mathrm{C} 3 \mathrm{H} / \mathrm{HeJ}$ mouse (Morrison et al., 1976; Sultzer \& Goodman, 1976). The protein content of these 'partially purified' preparations was 4-6\%, suggesting that they may have been contaminated with some mitogenic proteins. In this regard, we found that an endotoxin preparation extracted from $F$. nucleatum by the butanol/water procedure reported by Morrison \& Leive (1975) was rich in protein, and strongly mitogenic for $\mathrm{C} 3 \mathrm{H} / \mathrm{HeJ}$ spleen cells (data not shown).

The present study also revealed that LPSs from Fusobacterium species enhance glucose utilization by murine macrophages (Figs 3 and 4). Macrophages activated by LPS secrete various biologically active substances (Vogel \& Mergenhagen, 1982). Among these substances, IL-1 possesses many activities, such as stimulation of thymocyte proliferation and activation of B cells (Dinarello, 1984). Gowen et al. (1983) showed that an IL-1-like factor stimulated bone resorption in organ cultures of mouse calvaria. In the present study, we found that the LPS preparations from Fusobacterium species stimulated IL-1 production by mouse peritoneal macrophages. Furthermore, we have recently found that LPS from Fusobacterium species stimulates bone resorption in the mouse calvaria system (unpublished data). These findings suggest that Fusobacterium LPS may contribute to alveolar bone loss in the development of chronic periodontitis.

Obligatorily anaerobic Gram-negative filamentous rods such as Fusobacterium and Bacteroides species are opportunistic pathogens in man and animals. These types of infection are frequently of mixed aetiology. Price \& McCallum (1986) demonstrated that the growth factor produced by $F$. necrophorum, which maintains the growth of Bacteroides intermedius, is LPS. Enhancement of the growth of oral Bacteroides species by F. necrophorum or other Fusobacterium species may occur in the subgingival flora in the gingival crevice of patients with periodontal diseases.

Taking these findings together, the endotoxic substances from Fusobacterium species may contribute to the destruction of infected tissues like the periodontium, possibly as pathogenic mediators.

\section{REFERENCES}

Cunningham, A. J. \& Szenberg, A. (1968). Further improvements in the plaque technique for detecting single antibody-forming cells. Immunology 14, 599600.

Dinarello, C. A. (1984). Interleukin-1. Reviews of Infectious Diseases 6, 51-95.

DUERDEN, B. I. (1983). Infections due to Gramnegative non-sporing anaerobic bacilli. In Topley and Wilson's Principles of Bacteriology, Virology and Immunity, 7th edn, vol. 3, pp. 311-326. Edited by G. Wilson, A. Miles \& M. T. Parker. London: Butler \& Tanner.
Garcia, M. M., Charlton, K. M. \& MCKay, K. A. (1975). Characterization of endotoxin from Fusobacterium necrophorum. Infection and Immunity 11, 371-379.

GOWEN, M., WoOd, D. D., IHRIE, E. J., MCGuIRE, M. K. B. \& RusselL, R. G. G. (1983). An interleukin 1 like factor stimulates bone resorption in vitro. Nature, London 306, 378-380.

Hase, S., Hofstad, T. \& Rietschel, E. T. (1977). Chemical structure of the lipid A component of lipopolysaccharides from Fusobacterium nucleatum. Journal of Bacteriology 129, 9-14. 
Hawley, C. E. \& Falkler, W. A. (1978). The anticomplementary activity of lipopolysaccharide preparations and sonicates from a strain of Fusobacterium nucleatum. Journal of Periodontal Research 13, 24-36.

HoFstaD, T. (1982). Immunochemical studies of partially hydrolyzed lipopolysaccharide from Fusobacterium nucleatum ATCC 10953. Acta pathologica, microbiologica et immunologica scandinavica $\mathbf{B 9 0}$, 289-293.

Hofstad, T. \& Skaug, N. (1980). Fatty acids and neutral sugars present in lipopolysaccharides isolated from Fusobacterium species. Acta pathologica, et microbiologica scandinavica B88, 115-120.

Holdeman, L. V., Kelley, R. W. \& Moore, W. E. C. (1984). Family 1. Bacteroidaceae. In Bergey's Manual of Systematic Bacteriology, vol. 1, pp. 602-637. Edited by N. R. Krieg. Baltimore: Williams \& Wilkins.

IRving, J. T., Socransky, S. S. \& TANner, A. C. R. (1978). Histological changes in experimental periodontal disease in rats monoinfected with gramnegative organisms. Journal of Periodontal Research 13, 326-332.

JACOBS, D. M. \& MORRISON, D. C. (1977). Inhibition of the mitogenic responses to lipopolysaccharide (LPS) in mouse spleen cells by polymyxin B. Journal of Immunology 118, 21-27.

JoINER, K. A., MCADAM, K. P. W. J. \& KASPER, D. L. (1982). Lipopolysaccharides from Bacteroides fragilis are mitogenic for spleen cells from endotoxin responder and nonresponder mice. Infection and Immunity 36, 1139-1145.

Koga, T., Nishihara, T., Fujiwara, T., Nisizawa, T., OKahashi, N., Noguchi, T. \& Hamada, S. (1985). Biochemical and immunobiological properties of lipopolysaccharide (LPS) from Bacteroides gingivalis and comparison with LPS from Escherichia coli. Infection and Immunity 47, 638-647.

KRISTOFFERSEN, T. \& HofSTAD, T. (1970). Chemical composition of lipopolysaccharide endotoxins from human oral fusobacteria. Archives of Oral Biology 15, 909-916.

Mashimo, J., Yoshida, M., Ikeuchi, K., Hata, S., Arata, S., Kasai, N., OKuda, K. \& Takazoe, I. (1985). Fatty acid composition and Shwartzman activity of lipopolysaccharides from oral bacteria. Microbiology and Immunology 29, 395-403.

MOORE, W. E. C., RaNNey, R. R. \& Holdeman, L. V (1982). Subgingival microflora in periodontal disease : cultural studies. In Host-Parasite Interactions in Periodontal Diseases, pp. 13-26. Edited by R. J. Genco \& S. E. Mergenhagen. Washington, DC: American Society for Microbiology.

MorRison, D. C. \& LeIVE, L. (1975). Fractions of lipopolysaccharide from Escherichia coli O111:B4 prepared by two extraction procedures. Journal of Biological Chemistry 250, 2911-2919.

MoRrison, D. C., BeTZ, S. J. \& JACOBS, D. M. (1976). Isolation of a lipid $\mathrm{A}$ bound polypeptide responsible for 'LPS-initiated' mitogenesis of $\mathrm{C} 3 \mathrm{H} / \mathrm{HeJ}$ spleen cells. Journal of Experimental Medicine 144, 840-846.

Nair, B. C., MayberRy, W. R., Dziak, R., Chen, P. B., Levine, M. J. \& HausmanN, E. (1983). Biological effects of a purified lipopolysaccharide from Bacteroides ginginvalis. Journal of Periodontal Research 18 40-49.
Nygren, H., Dahlen, G. \& Nilsson, L.-A. (1979). Human complement activation by lipopolysaccharides from Bacteroides oralis, Fusobacterium nucleatum, and Veillonella parvula. Infection and Immunity 26, 391-396.

Price, S. B. \& MCCAllum, R. E. (1986). Enhancement of Bacteroides intermedius growth by Fusobacterium necrophorum. Journal of Clinical Microbiology 23, 22-28.

Ryan, J. L., Glode, L. M. \& Rosenstreich, D. L. (1979). Lack of responsiveness of $\mathrm{C} 3 \mathrm{H} / \mathrm{HeJ}$ macrophages to lipopolysaccharide: the cellular basis of LPS-stimulated metabolism. Journal of Immunology 122, 932-935.

SAVITT, E. D. \& SocranSKy, S. S. (1984). Distribution of certain subgingival microbial species in selected periodontal condition. Journal of Periodontal Research 19, 111-123.

Shapiro, L., Lodato, F. M., Courant, P. R. \& STALlaRD, R. E. (1972). Endotoxin determinations in gingival inflammation. Journal of Periodontology 43, 591-596.

Simon, B., Goldman, H., Ruben, M., Broitman, S. \& BAKER, E. (1972). The role of endotoxin in periodontal disease. IV. Bacteriologic analysis of human gingival exudate as related to the quantity of endotoxin and clinical degree of inflammation. Journal of Periodontology 43, 468-475.

SLOTs, J. (1979). Subgingival microflora and periodontal disease. Journal of Clinical Periodontology 6, 351382.

Socransky, S. S., TanNer, A. C. R., Haffajee, A. D., Hillman, J. D. \& Goodson, J. M. (1982). Present status of studies on the microbial etiology of periodontal diseases. In Host-Parasite Interactions in Periodontal Diseases, pp. 1-12. Edited by R. J. Genco \& S. E. Mergenhagen. Washington, DC: American Society for Microbiology.

SUltzer, B. M. \& Goodman, G. W. (1976). Endotoxin protein: a B-cell mitogen and polyclonal activator of C $3 \mathrm{H} / \mathrm{HeJ}$ lymphocytes. Journal of Experimental Medicine 144, 821-827.

SVEEN, K. (1977). The capacity of lipopolysaccharides from Bacteroides, Fusobacterium and Veillonella to produce skin inflammation and the local and generalized Shwartzman reaction in rabbits. Journal of Periodontal Research 12, 340-350.

SVEEN, K. \& SKaUG, N. (1980). Bone resorption stimulated by lipopolysaccharides from Bacteroides, Fusobacterium and Veillonella, and by the lipid $A$ and the polysaccharide part of Fusobacterium lipopolysaccharide. Scandinavian Journal of Dental Research 88, 535-542.

Sveen, K., Hofstad, T. \& Milner, K. C. (1977). Lethality for mice and chick embryos, pyrogenicity in rabbits and ability to gelate lysate from amoebocytes of Limulus polyphemus by lipopolysaccharides from Bacteroides, Fusobacterium and Veillonella. Acta pathologica et microbiologica scandinavica B85, 388-396.

Vacheron, F., Gueonounou, M. \& Nauciel, C. (1983). Induction of interleukin 1 secretion by adjuvant-active peptidoglycans. Infection and Immunity 42, 1049-1054.

Vogel, S. N. \& Mergenhagen, S. E. (1982). Cellular basis of endotoxin susceptibility, In Host-Parasite Interactions in Periodontal Diseases, pp. 160-168. 
Edited by R. J. Genco \& S. E. Mergenhagen. Washington, DC: American Society for Microbiology.

Warner, J. F., Fales, W. H., Sutherland, R. C. \& TERESA, G. W. (1975). Endotoxin from Fusobacterium necrophorum of bovine hepatic abscess origin. American Journal of Veterinary Research 36, 10151019.

WestPhal, O. \& JANN, K. (1965). Bacterial lipopolysaccharides. Extraction with phenol-water and further applications of the procedure. Methods in Carbohydrate Chemistry 5, 83-91.

Williamson, S. I., WANNEMuEhLER, M. J., JiRillo, E., Pritchard, D. G., Michalex, S. M. \& McGheE, J. R. (1984). LPS regulation of the immune response: separate mechanisms for murine $B$ cell activation by lipid A (direct) and polysaccharide (macrophagedependent) derived from Bacteroides LPS. Journal of Immunology 133, 2294-2300.

Wollenweber, H. W., Rietschel, E. T., Hofstad, T., Weintraub, A. \& Lindberg, A. A. (1980). Nature, type of linkage, quantity, and absolute configuration of (3-hydroxy) fatty acids in lipopolysaccharides from Bacteroides fragilis NCTC 9343 and related strains. Journal of Bacteriology 144, 898903.

Wollenweber, H. W., Seydel, U., Lindner, B., LÜDERITZ, O.\& RIETSCHEL, E. T. (1984). Nature and location of amide-bound $(R)$-3-acyloxyacyl groups in lipid A of lipopolysaccharides from various Gramnegative bacteria. European Journal of Biochemistry 145, 265-272. 